\title{
THE INFLUENCE OF SILICEOUS MINERAL PHASES ON THE MECHANICAL PROPERTIES OF TRANSITIONAL ROCKS IN THE BELCHATOW LIGNITE DEPOSIT
}

\begin{abstract}
A. PEKALA ${ }^{1}$
The transitional siliceous rocks from the Belchatow lignite deposit belong to the deposits with heterogeneous petrographic composition. The research allows us to identify among others, opoka-rocks and gaizes. The mineralogical-chemical analysis proves that the main ingredients of the studied rocks commonly used as building material are minerals of the $\mathrm{SiO}_{2}$ group. Laboratory tests show that the nature of siliceous mineral phases has several effects on the geomechanical parameters of the studied transitional rocks. They are a reduction in water content and rock porosity, which leads to the transition of opal type A to opal type crystobalit and trydymit and then to quartz or microquartz. Their density and strength parameters are increased.
\end{abstract}

Keywords: transitional rocks, mineral $\mathrm{SiO}_{2}$, Belchatow lignite deposit, geomechanical properties

\section{INTRODUCTION}

Economic and civil development is indispensably associated with increasing demand for mineral resources. This situation forces exploration into new alternative sources of recovering them. In the course of the extraction operation of lignite in the Belchatow lignite, it was found that both the overburden rocks and Mesozoic bedrock contained minerals having valuable raw material properties. The carried out mineralogical-petrographic studies help to identify, in the contact of the Mesozoic bedrocks with Neogene sediments in the Belchatow lignite deposit, a group of siliceous

\footnotetext{
${ }^{1}$ PhD., Eng., Rzeszow University of Technology, Faculty of Civil, Environmental Engineering and Architecture, ul. Poznanska 2,35-959 Rzeszow, Poland, e-mail: apekala@prz.edu.pl
} 
rocks with transitional character such as opoka-rocks and gaizes [1,2]. A variety of phases of silica can be determined in these rocks on the basis of microscopic and rentgenographic criteria. The substance $\mathrm{SiO}_{2}$ belongs to crystal-chemical compounds of a complex nature. This substance can create numerous polymorphic forms depending on the environmental conditions in which its crystallization occurs. There we find: opal, crystobalit, trydymit, chalcedony and quartz (fig.1).

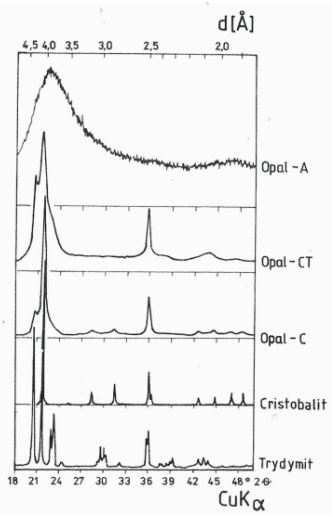

Fig.1. X-ray pattern of different varieties of opal and chalcedony, and trydymit and crystobalit $[3,4]$

The content of various polymorphic varieties of silica often determine the geomechanical properties of rocks. The carried out laboratory studies show that the possibility of the practical application of the studied rocks is dependent on the quantity and, in particular, on the phase character of minerals in the $\mathrm{SiO}_{2}$ group that are present among them. As a result of the transformation of siliceous mineral phases in the rock, there are physical changes - mechanical features. As a result, in the transition of opal type A to quartz, there is a reduction of water content, porosity and permeability within the rock. An increase of temperature, pressure, alkalinity and the presence of various catalysts can accelerate the process of these changes. The presence of clayey minerals causes the slowing rate of these processes. The transitional siliceous rocks have practical importance as mineral resources of a mixed type. Opoka-rocks differentiate from other rocks by their abundance of cryptocrystalline, fine scattered silica among carbonate components. Their characteristic feature is the presence of spatial structures composed of opal or chalcedony. Leaching of $\mathrm{CaCO}_{3}$ in the weathering zone leads to the forming of a porous residual deposit that is known as light opoka-rock. Opoka-rocks and gaizes are from the Cretaceous age and occur in large areas of Lublin Upland, along the central banks of the Vistula River near Lodz and in the Miechowska Basin. They are used for the local construction industry[5]. Gaizes are used locally as a building and road stone. Numerous studies and practice 
confirm the usefulness of both minerals for the production of cement, including cement of special quality [6].

\section{RESEARCH MATERIAL AND METHODOLOGY}

Samples that were taken from the cores prior to the exploitation front of the Belchatow and Szczercow mining fields were the basis for the carried out studies. The research material was supplemented by addition of samples from the southern slope of the outcrop from the Belchatow field. Throughout the field and laboratory work there were a total of 92 rock samples which were analysed. 57 rock samples came from boreholes and 35 from the exploitation slope. The studied transitional rocks were found in 22 samples. The largest number was composed of opoka-rocks, which were found in 18 samples, and gaizes in 4 samples. The carried out laboratory analyses included a wide methodological spectrum. The most important studies covered:

- The mineralogical properties were determined with the use of: polarization microscope Olimpus BX-51; scanning electron microscopy (SEM) FEI Quanta 200FEG and X-ray diffraction using a Philips X'Pert diffractometer with reflective monochromatyzer.

- The chemical properties were determined by atomic absorption spectroscopy (AAS) using a spectrophotometer Philips PU 9100Xi Camera SX-100 and atomic emission spectroscopy with inductively coupled plasma (ICP AES) using a spectrometer PLASMA 40

- The geomechanical parameters important for structural materials were determined in accordance with existing standards. It was determined by: open and total porosity (PN- EN 1936: 2001)[7]; compressive strength in air - dried state (PN-EN 1926: 2001)[8]; bulk density and density (PN- EN 1936: 2001)[7].

\section{RESEARCH RESULTS AND DISCUSSION}

The subject of the research in this paper is a group of the transitional siliceous rocks represented by opoka-rocks and gaizes [4]. The carried out studies show that in all the recognized petrographic types of rocks, the dominant component is silica. Minerals from the $\mathrm{SiO}_{2}$ group occur in the form of opal type A and CT, chalcedony or quartz. The process of enrichment of the studied rocks containing silica is as follows:

- filling the fine primary and secondary pores,

- the appearance of coatings on detrital quartz grains in the form of regenerative rims on the gaizes, 
- pseudomorphs after replacement of carbonate minerals in the opoka- rocks,

- replacement of carbonate minerals by silica in bioclasts,

- occuring as cement in all types of presented rocks.

The carried out studies allow the declaration that the silica content in the opoka-rocks from the Belchatow lignite deposit is placed within the range from 40.20 to $66.90 \mathrm{wt} \%$. $\mathrm{CaO}$ share ranges from 16.00 to $30.50 \mathrm{wt} \%$. Due to the aforementioned large variation of silica and carbonate content in the rocks, two types of rock can be identified: silicified opoka-rocks and light opoka-rocks. The silification process quite clearly distinguishes itself in the microscopic image. The silica replacing carbonates in the rocks is represented by chalcedony and opal type CT. It is created in the form of short fibers, forming focus in a radially centripetal system, simulating a fine-grained mosaic, and quartz grains are very rarely found [9]. X-ray studies (fig.2) show that the studied opoka-rocks are composed of a silica substance with character of opal type CT (crystobalit - trydymit), tridymite and quartz. Carbonate minerals are represented by calcite.

Among the transitional siliceous rocks from the Belchatow lignite deposit, macroscopical rocks which resembled sandstones or mudstones were also identified. They were identified as gaizes. They are mostly found accompanying opoka-rocks. The carried out chemical research which was done with gaizes show that they are mainly composed of silica that is greater than $93 \%$ wt. of its quantitative composition. The content of $\mathrm{CaO}$ is placed in ranges from 0.50 to $19.82 \%$ wt. The texture of these rocks is random, slightly porous and the structure is organodetritic. Rocky cement is determined by cryptocrystalline silica (fig.2). Detrital material is represented by siliceous organic skeletal elements, mainly needle sponges, shells of radiolarians and diatoms. Furthermore, biotite and partly chloritized biotite and quartz grains have been found within the detrital material the blades of hydromuscovite and muscovite [10].

For the analysed X RAY patterns, an increase of background on X-ray diffractometers on an angular range of $2 \mathrm{Q}_{\mathrm{CuKa}} 18-24^{0}$ exists, which suggests the presence of opal - type A [3]. It can be noticed, however, that there is a clear reflection of the value $2 \mathrm{Q}_{\text {CuKa }} 22,5^{\circ}$, and $2 \mathrm{Q}_{\mathrm{CuKa}} 36^{\circ}$. These reflections are related with the presence of partially ordered varieties of minerals from the $\mathrm{SiO}_{2}$ group: opal- type CT (crystobalit - trydymit) relative to the opal - type C (crystobalit) (fig.2). 


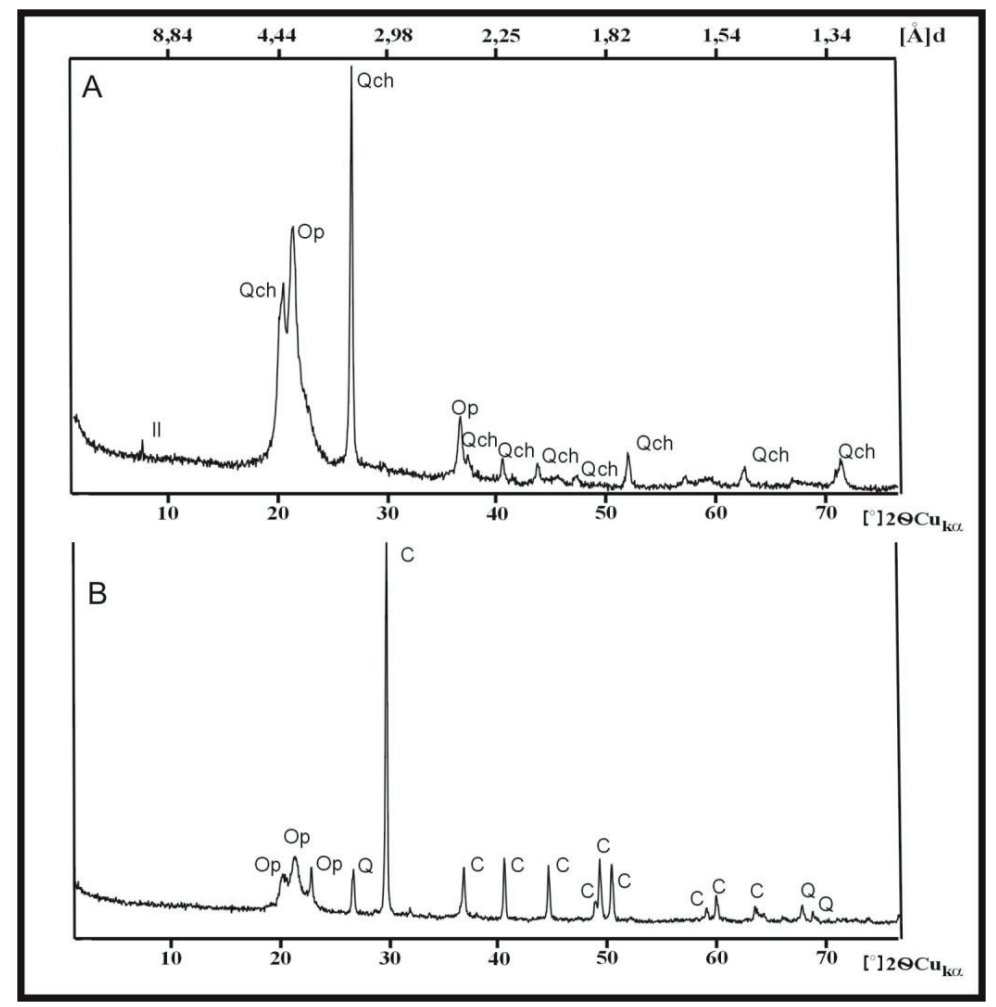

Fig.2. Example diffractometry curves for gaizes - (A), opoka-rocks (B). Explanation of symbols:

Op - opal type CT (crystobalit - trydymit), Och - chalcedony, Q - quartz, C - calcite, I - illite

In addition, X-ray research was carried out to determine the crystallinity index of quartz CI [11], the value of which is related to the visibility degree of reflex $d(212)=1.3020$ A. According to the methods, pure idiomorphic quartz has a clarity $\mathrm{CI}=10$ and poorly crystallized silica $\mathrm{CI}<1.0$. The crystallinity index results seem to be largely a function of the size of the crystallites larger than 1 micrometer in diameter, but may also be dependent on network deformation caused by mechanical stresses. In the opoka-rocks CI range from 1.8 to 2.17 . In the case of the gaizes, the CI value equals 7.8 (fig.3). The carried out study showed a fairly high degree of order of silica phases in the gaizes and a distinct difference in the forming of silica building the studied transitional rocks. The results are comparable with the standard quartz from Jeglowa and chalcedonites from the Tomaszow Basin (fig.3). 


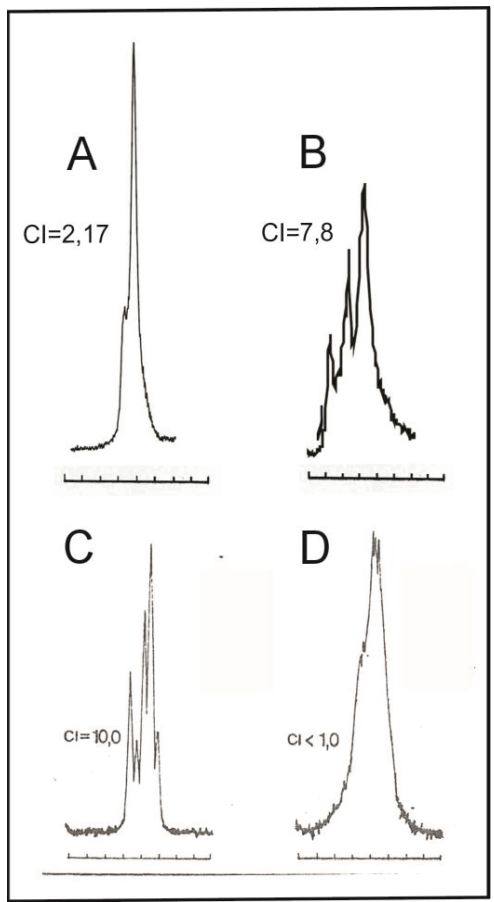

Fig.3. The degree of quartz crystallinity $\mathrm{CI}[11]$ in the transitional rocks from the Belchatow lignite deposit Explanation: A- opoka-rock sample, B- gaize sample, C-model sample of quartz from Jeglowa, D- chalcedony sample from Teofilow

Among the physical and mechanical parameters that were tested for transitional siliceous rocks it should be noted the fact that the opoka-rocks covered by the silification processes show a significantly lower values of total porosity. The maximum value of this parameter in these rocks is 24,3 (vol.\%) and in the opoka-rocks covered by calcination processes this parameter does not exceed 44, 5 (vol.\%). The compressive strength in the air-dried state of the silicified opoka-rocks is much larger (52.0 MPa) as compared to the decalcified opoka-rocks (31.9 MPa). Furthermore, silicified opoka-rocks have a higher apparent density - $1.9 \mathrm{~g} / \mathrm{cm}^{3}$. Apparent density in the decalcified opoka-rocks is placed in the range from 1.32 to $1.41 \mathrm{~g} / \mathrm{cm}^{3}$ which allows its inclusion to the so-called light opoka-rocks. Tested gaizes also show a high value of compressive strength (Rc) in the range of $55 \mathrm{MPa}$ [9]. Comparing the results of the geomechanical properties of opoka-rocks and gaizes from the Belchatow mining field with the results of transitional sediments from the 
Lublin Upland we might have noticed that these rocks were characterized by a high mechanical strength. (much larger 52.0 MPa).Compressive strength in the air-dried state of the Cretaceous opoka- rocks and gaizes from the Lublin Upland, Pinińska J. [12] was in the range of 10 to $40 \mathrm{MPa}$, what classify them to the rocks with low and medium stength (PN-EN -ISO-14689)[13]. In addition, these rocks had a higher apparent density $-1.9 \mathrm{~g} / \mathrm{cm}^{3}$ and lower water absorption - $11 \%$. Meanwhile, the density and water absorption for opoka - rocks from the Lublin Upland was, respectively, $1.4-1.6 \mathrm{~g} / \mathrm{cm} 3, \mathrm{n}>35 \%$. The attention is the fact that the geomechnical characteristics of the opoka - rocks of the Lublin region are related to the micritic structure of these rocks reinforced a significant amount of siliceous needles of sponges. Thanks to the skeletal strengthening of the opoka- rocks they are harder to cracking and are more resistant to mechanical destruction processes in comparision with other local carbonate raw materials of similar density and strength. In the carried out mineralogical research of the Belchatow opoka - rocks there was not found any needles of sponges in the microscopic images, whereas the strengthening of the structure of these rocks is the result of secondary mineralization processes, mainly replacing carbonate minerals by silica minerals.

By analyzing the obtained results it can be concluded that not only the quantity but also the type of silica mineral phase affects the geotechnical parameters of the studied rocks. With increasing crystallinity index (CI) there is an increase in parameters such as the compressive strength in an airdried state and apparent density. Their porosity decreases. tab (1).

Table.1 Transitional siliceous rocks with dominant mineral from group of $\mathrm{SiO}_{2}$ and designated parameter

\begin{tabular}{|c|c|c|c|}
\hline \multirow{2}{*}{ Parameters } & \multicolumn{3}{|c|}{ Kind of rock with dominant mineral with $\mathrm{SiO}_{2}$} \\
\hline & $\begin{array}{l}\text { Opoka -rocks } \\
(\text { Opal A-CT) }\end{array}$ & $\begin{array}{c}\text { Silicified opoka-rocks } \\
\text { (Opal type CT in relative } \\
\text { of Opal type C) }\end{array}$ & $\begin{array}{c}\text { Gaize } \\
\text { (Chalcedony - Quartz) }\end{array}$ \\
\hline $\begin{array}{l}\text { Porosity (\% obj.) } \\
\text { DECREASE }\end{array}$ & 44,5 & 24,3 & 10 \\
\hline $\begin{array}{l}\text { Density }\left(\mathrm{g} / \mathrm{cm}^{3}\right) \\
\text { INCREASE }\end{array}$ & $1,32-1,41$ & 1,9 & n. $o$ \\
\hline $\begin{array}{lll}\text { Compressive } & \text { Strength } & (\mathrm{MPa}) \\
\text { INCREASE } & & \\
\end{array}$ & 31,9 & 52 & 55 \\
\hline $\begin{array}{l}\text { Crystallinity index* } \\
\text { INCREASE }\end{array}$ & 1,8 & 2,17 & 7,8 \\
\hline
\end{tabular}

* X-ray determined by Murat and Norman method

n. o. - not determined 


\section{SUMMARY}

- The carried out studies show a fairly high degree of silica phase in the gaizes and distinct differences in the forming of silica in the studied transitional rocks. It can be noticed that for the most part, the studied rocks were covered by a recrystallization processes which consisted of the conversion of opal to chalcedony and microcrystalline quartz. This process is related to the gradual or total obliteration of the original textures and a transformation involving the transition from rocks with organic structures to rocks with microcrystalline structures. It leads to the increase of compaction and reduction of porosity.

- The quantity and phase nature of the minerals from the $\mathrm{SiO}_{2}$ group primarily has an effect on the possibility of the practical application of the studied transitional rocks. Presence of such a high silica content and its phase variation has an influence on their strength parameters. With increasing crystallinity index (CI), an increase of parameters, such as the compressive strength in air-dried state and apparent density, is observed. Their porosity decreases.

Investigations were carried out as part of research contract U-604/DS 


\section{REFERENCES}

1. T. Ratajczak, I. Kosk, J. Pabis, "Osady zwietrzelinowe ze strefy kontaktowej trzeciorzęd mezozoik w złożu węgla brunatnego „Bełchatów” - ich litologia, charakter surowcowy i możliwości wykorzystania”[Weathered sediments from the Mesozoic-Tertiary contact zone in the Belchatow lignite deposit - their lithology, raw material character and possibility of use]. IGSMiE PAN 56, Krakow, Poland, 2002

2. A. Gilarska, E. Stachura, „Charakterystyka mineralogiczno-petrograficzna skał krzemionkowych ze strefy kontaktu trzeciorzęd-mezozoik w złożu węgla brunatnego „Bełchatów”. [Mineralogical and petrographic characteristic of the siliceous rocks of the Tertiary-Mesozoic contact zone in the Belchatow lignite deposit]. Zeszyty Naukowe Politechniki Śląskiej, Seria Górnictwo 269, pp 97-107, 2005.

3. O.W. Flörke, H. Graetsch, B. Martin, K. Röller, R. Wirth,” Nomenclature of micro- and non-crystalline silica minerals, based on structure and microstructure”. Neues Jahrbuch für Mineralogie. Abhandlungen 163,pp.1942,1991

4. A. Manecki, A. Muszyński (Eds.). „Przewodnik do petrografii”. [Guidebook to petrography]. Kraków: AGH University of Science and Technology, 2008

5. S. Kozłowski, „Surowce skalne Polski”, Wyd. Geol., Warszawa, 1986

6. B .Bąk, A. Szeląg, „Opoki i gezy - zapomniane kopaliny Lubelszczyzny”. Górnictwo Odkrywkowe.54, no 2,pp 107-116, 2013

7. PN-EN 1936:2010. Metody badań kamienia naturalnego. Oznaczanie gęstości objętościowej oraz całkowitej i otwartej porowatości [Polish Standard. Methods of test for natural stone. Determination of bulk density, total and open porosity].

8. PN-EN 1926:2001. Metody badań kamienia naturalnego. Oznaczenie wytrzymałości na ściskanie w stanie powietrzno-suchym [Polish Standard. Methods of test for natural stone. Determination of compressive strength in the air-dried state].

9. A. Pękala „The mineral character and geomechanical properties of the transitional rocks from the mesozoic neogene contact zone in the Bełchatów lignite", Journal of Sustainable Mining, 13(1), pp 3-9, 2014

10. A. Pękala,. „Charakterystyka mineralogiczno-geochemiczna skał przejściowych ze strefy kontaktu mezozozik - neogen w złożu węgla brunatnego „Bełchatów”. [Mineralogical - geochemical study of the transitional rocks from the Mesozoic - Neogen contact zone in the "Bełchatów" lignite deposit]. Górnictwo i Geologia 7(2), pp $187-205,2012$

11. K.J. Murata, M.B Norman., An index of crystallinity for quartz”. Amer. Jour. Sci. 276, pp 1120 - 1130,1976

12. J. Pinińska,. „Właściwości geomechaniczne opok”, [Geomechanical properties of opoka-rocks], Górnictwo i Geoinżynieria, 32(1), 293-301, 2008.

13. PN-EN- ISO 14689-1:2003. Geotechnical investigation and testing - Identification and classification of rock Part 1: Identification and description. 


\section{LIST OF FIGURES AND TABLES:}

Fig.1. X-ray pattern of different varieties of opal and chalcedony as well as comparatively trydymit and cristobalit

Rys. 1 Dyfraktogramy rentgenowskie różnych odmian opalu oraz porównawczo trydymitu i cristobalitu

Fig.2 Example diffractometry curves for gaizes (A), opoka -rocks (B). Explanation of symbols: Op - opal type CT (crystobalit - trydymit), Och - chalcedony, Q - quartz, C - calcite, I - illite.

Rys.2 Przykładowe krzywe dyfraktometryczna dla gez (A), opoka (B). Objaśnienia stosowanych symboli: Op - opal typu CT (crystobalitowo - trydymitowy), Och - chalcedon, Q - kwarc, C- kalcyt, I - illit Fig. 3 The degree of quartz crystallinity $\mathrm{CI}$ in the transitional rocks from the Belchatow lignite deposit Explanation: A- opoka-rock sample , B- gaize sample, C-model sample of quartz from Jeglowa, Dchalcedony sample from Teofilow

Rys.3 Stopień krystaliczności kwarcu CI w przejściowych utworach krzemionkowych ze złoża Bełchatów. Objaśnienia: A- próbka opoki , B- próbka gezy, C-próbka wzorcowa kwarcu z Jegłowej, D-.próbka chalcedonu z Teofilowa.

Tab. 1 Transitional siliceous rocks with dominant mineral from the group of $\mathrm{SiO}_{2}$ and designated parameter Tab. 1 . Skały przejściowe z dominującym minerałem z grupy $\mathrm{SiO}_{2}$ oraz wyznaczony parametr 


\section{WPLYW KRZEMIONKOWYCH FAZ MINERALNYCH NA WLASNOŚCI GEOMECHANICZNE SKAL PRZEJŚCIOWYCH ZE ZLOŻA WĘGLA BRUNATNEGO „BELCHATÓW”}

Słowa kluczowe: skały przejściowe, minerały z grupy SiO2, złoże węgla brunatnego Bełchatów, parametry geomechaniczne

\section{STRESZCZENIE}

Przedmiotem prezentowanych badań mineralogiczno - geomechnicznych jest grupa skał przejściowych tj. opoki i gezy, odsłaniających się na kontakcie osadów neogeńskich z utworami podłoża mezozoicznego w złożu Bełchatów. Badania mineralogiczno - chemiczne dowiodły, że głównym składnikiem omawianych skał będących często materiałem budowlanym, są minerały $\mathrm{z}$ grupy $\mathrm{SiO}_{2}$. Badania laboratoryjne wykazały, że charakter krzemionkowych faz mineralnych wpływa niejednokrotnie na cechy geomechaniczne badanych utworów przejściowych. W efekcie przejścia opalu -A w opal crystobalitowo - trydymitowy a następnie w chalcedon czy kwarc dochodzi do zmniejszenia w skałach zawartości wody czy porowatości. Wzrasta zaś ich gęstość oraz parametry wytrzymałościowe.

W ramach badań mineralogicznych wykorzystano mikroskopy: polaryzacyjny Olimpus BX-51 oraz elektronowy (SEM) FEI Quanta 200FEG. Określenia składu jakościowego i ilościowego zrealizowano za pomocą dyfraktometru rentgenowskiego PHILIPS X'PERT PW 3020. Skład chemiczny oznaczono metodą atomowej spektroskopii absorpcyjnej (ASA) oraz atomowej spektroskopii emisyjnej z plazmą wzbudzoną indukcyjnie (ICP AES). Własności geomechaniczne ustalono zgodnie z obowiązującymi normami: porowatość otwarta i całkowita (PN-EN 1936:2001); wytrzymałość na ściskanie w stanie powietrzno - suchym (PN-EN-1926:2001); gęstość objętościowa i właściwa (PN-EN-1936:2001).

Wykonane badania chemiczne wykazały w opokach ze złoża „Bełchatów” zawartość krzemionki w przedziale od 40,20 do $66,90 \%$ wag.. Udział $\mathrm{CaO}$ waha się w zakresie od 16,00 do 30,50 \% wag. W przypadku gez, krzemionka stanowi ponad 93\% wag. składu ilościowego skał. Zawartość CaO zaś kształtuje się od 0,50 do 19,82 \% wag. Dodatkowo dla przedmiotowych skał przeprowadzono badania rentgenograficzne w celu określenie wskaźnika krystaliczności kwarcu CI, którego wielkość związana jest ze stopniem wyrazistości refleksu d(212) =1,3020 A. Zgodnie z założeniami metody, czysty idiomorficzny kwarc wykazuje wyrazistość $\mathrm{CI}=10$, słabo zaś skrystalizowana krzemionka $\mathrm{CI}<1,0$. Wskaźnik krystaliczności wydaje się w dużym stopniu funkcją rozmiaru krystalitów większych od $1 \mu$ m średnicy, ale może być również zależny od deformacji sieciowych wywołanych przez naciski mechaniczne. W opok CI mieścił się w przedziale od 1,8 -2,17. W przypadku gez wartość CI wyniosła 7,8. Przeprowadzone badania wykazały dość wysoki stopień uporządkowania fazy krzemionkowej w gezach i wyraźną różnicę w wykształceniu krzemionki budującej badane skały przejściowe. Analizując uzyskane wyniki badań można stwierdzić, że nie tylko ilość ale również rodzaj krzemionkowych faz mineralnych ma wpływ na parametry geotechniczne badanych skał. Wraz ze wzrostem współczynnika krystaliczności (CI) dochodzi do wzrostu wartości parametrów takich jak wytrzymałość na ściskanie w stanie powietrzno-suchym oraz gęstość pozorna, maleje zaś ich porowatość (tab.1).

Porównując uzyskane wyniki właściwości geomechanicznych opok i gez ze złoża Bełchatów z wynikami dla tych utworów z regionów Wyżyny Lubelskiej, można zauważyć iż badane skały charakteryzują się znaczną wytrzymałością mechaniczną. Wytrzymałość na ściskanie w stanie powietrzno suchym opok i gez kredowych Wyżyny Lubelskiej wg. J. Pinińska (2008) jest rzędu od 10 do $40 \mathrm{MPa}$, co klasyfikuje je zgodnie z normą PN-EN -ISO-14689 do skał o niskiej i średniej wytrzymałości. Ponadto skały te posiadają wyższa gęstość pozorną $-1,9 \mathrm{~g} / \mathrm{cm}^{3}$ oraz niższą nasiąkliwość - $11 \%$. 
Tymczasem wartości gęstości oraz nasiąkliwości dla opok lubelszczyzny wynoszą odpowiednio: $\rho_{\mathrm{s}}$ od 1,4 do 1,6 g/ $\mathrm{cm}^{3}$, zaś $n>35 \%$. Na uwagę zwraca również fakt, że cechy geomechaniczne opok Lubelszczyzny są związane z mikrytową strukturą tych skał wzmocnioną znaczna ilością krzemionkowych igieł gąbek. Dzięki temu rusztowemu wzmocnieniu opoki trudniej ulegają pękaniu i na tle innych lokalnych surowców węglanowych o podobnej gęstości i wytrzymałości, są bardziej odporne na procesy mechanicznej destrukcji. W przeprowadzonych badaniach mineralogicznych dla opok bełchatowskich w obrazach mikroskopowych nie stwierdzono igieł gąbek, zaś wzmocnienie struktury tych skał jest wynikiem wtórnych procesów mineralizacyjnych, głównie zastępowaniu minerałów węglanowych przez minerały krzemionkowe.

Tabela 1. Skały przejściowe z dominującym minerałem z grupy $\mathrm{SiO}_{2}$ oraz wyznaczony parametr

\begin{tabular}{|c|c|c|c|}
\hline \multirow{2}{*}{ PARAMETR } & \multicolumn{2}{|c|}{ RODZAJ SKALY Z DOMINUJĄCYM MINERALEM Z SiO 2} \\
\cline { 2 - 4 } & $\begin{array}{c}\text { Opoka } \\
\text { (Opal A - CT) }\end{array}$ & $\begin{array}{c}\text { Opoka sylifikowana } \\
\text { (Opal typu CT z } \\
\text { przejściem do opal } \\
\text { type C) }\end{array}$ & $\begin{array}{c}\text { Geza } \\
\text { (chalcedon - kwarc) }\end{array}$ \\
\hline $\begin{array}{c}\text { Porowatość (\% obj.) } \\
\text { Maleje }\end{array}$ & 44,5 & 24,3 & 10 \\
\hline $\begin{array}{c}\text { Gęstość (g/cm }{ }^{3} \text { ) } \\
\text { Rośnie }\end{array}$ & $1,32-1,41$ & 1,9 & \\
\hline $\begin{array}{c}\text { Wytrzymałość na ściskanie (MPa) } \\
\text { Rośnie }\end{array}$ & 31,9 & 52 & 5 \\
\hline $\begin{array}{c}\text { Współczynnik krystaliczności* } \\
\text { Rośnie }\end{array}$ & 1,8 & 2,17 & 7,8 \\
\hline
\end{tabular}

*Wyznaczony rentgenograficznie metodą Murata i Normana n.o - nie oznaczono 